\title{
RESUME OF NOMENCLATURE COMMITTEE AND JUDICIAL COMMISSION MEETINGS AT RIO DE JANEIRO
}

\section{$S$, $T$. Cowan and R. S. Breed, Permanent Secretaries}

BOTH THE Judicial Commission and the Nomenclature Committee held a series of meetings during the fifth International Congress of Microbiology at Petropolis, Rio de Janeiro, in August, 1950. Most of the items were discussed first by the Commission and later by the Committee, which decided what action should be taken on matters referred to it.

Dr. A. Lwoff, who had been elected Chairman of the Com mittee at Copenhogen, opened the meeting and took the chair until Professor A. J. Kluyver was elected the new chairman. Dr. A.R. Prevot, the newly. elected vice chairman, took the chair at the second session. Professor R.E.Buchanan took the chair at all sessions of the Judicial Commission.

Members of the International Committee and of the Judicial Commission (names italicized) present were: Prof A. Sordelli and Ing. Santos Sori ano (Argen tina); Mr.W.J.Scott, alternate for Prof. Rubbo (Australia);

Dr。A Bitancourt (Brazi1):

Dr.A.C. Thaysen (British West Indies): Prof E. J, Mor in (Canada): Dr. Hugo Vaccaro (Chi le): Dr. F. Kauf fmann, Prof N. F Buchwald (Denmark): Dr, A . R. Prevot, Dr. A. Lwoff, Dr. Lepine, Dr. Segretain (France); Prof.C. Stapp, Prof. H. Schloss -berger, alternate for $\mathrm{Dr}$. Haupt (Germany); Dr.J.Rams bot tom, Dr. G. S. Wi l son, Dr, C. H. And̃rewes, Prof.H.Maitland, alternate for $\mathrm{Dr}$. Miles (Great Britain); Prof. A.J. Kluyver, Prof. J.W. Wolff, alternate for
Prof. Julius (Holland); Dr.M Ashner (Israe 1); Dr.G. Penso, Dr.P. Redaelli, al ternate for Dr.Ciferri (Italy); Prof. Th. Thjotta (Norway): Prof. Sven Gard (Sweden); Prof. R.E。 Buchanen, Dr. G.W. Rake, al ter. nate for Col. Hitchens, (U.S.A. ), Prof" E. Hormaeche (Uruguay); Dr.R. St. John Brooks (Li fe member ); Prof . Robert S. Breed and $\mathrm{Dr}$. $\mathrm{S} . \mathrm{T}_{\text {o }}$ Cowan, Permanent Secretaries.

Dr。R.St. John-Brooks, after acting for twenty years as one of the permanent secretaries, asked to be released from these duties. In both the Committee and the Commission the chai rmen expressed regret that Dr R. St John-Brooks felt compelled to give up this work; they thanked him for all the effort he had put into his work as permanent secretary for medical and veterinary bacteriology, and expressed the hope that he would be the first $\mathrm{Life}$ Member of the Committee.

Professor Buchanan, Chairman of the Commission, reported that the of ficial text of the International Bacteriological Code of Nomenclature had been printed in English, and that unofficial translations had been made into French, German, and Spanish. While it is most desirable that the Code should be translated into different 1 anguages the Commission felt that some control should be exercised over the translations.

Amendments to the code Several amendments to the bac- 


\section{BACTERIOLOGICAL NOMENCLATURE AND TAXONOMY}

teriological Code had been pro posed and were considered first by the Commission which made recommendations to the Conmitiee Recominendations ac cepted by the Committee became effecilve after their approval $y$ the Plenary Session of the Congress

A proposal that Frovision 4 of Chapter 4 of the Code be rescinded and replaced by new Provisions 4 and 5 was approved unanimously These new pro visions deline more definitely the constitution of the Inter national comictee on Bacteri. ological Nomenclature and the Judicial Comnission and the duties and functions of their menbers and officers. This anendinent is pubitshed in this BULETIK

A prowsal that the word taxun" and ics pinrai form "taxe siould be usco inclead of lexonumic group or "Eroups" was not accepted. but in was agreed that the words taxon and "taxa" siould be inserted in parenties s efier the wats iaxonomic gluus or houps wherever these occur in the Cooc

The amendiner t of Chapter 3 Rules 12,3 ans 4 , to tixe worcing used in the Botanical Code wrs discussed but the pro posal was not acceptable. it was agreed that the Hriforiat Board should ruake the changes necessary to squire that names of famities siblanilies. tribes and subtribes shalf be taken from the name of a con. tained genus and to frame a new Kccomendstion that in chosing a family nane: the sten of the nane of tic type genus be used.

It was agreed that Chapter 3. Rule $\mathbf{E}$ sliould have a phrasc adied to incl cate that citations of authors and dates are governed by Rule 10 This action was necessary because. when a genus becomes a subgenus the strict application of Rule 5 before amendment might pro duce a different result from the application of Rule 16

An amendment to Chanier 3 Rule 9 had been proposed with the object of laying down more definite rules for the seler tion of type species The discussion covered the whole type concept and was not re. stricted to type species and type cultures It was decided to appoint a special committee Dr Prevot. Dr. Ramsibottom and the Editorial Board to cunsider. the working of the anenced rule and to submit the finai pro posal to a postal ballot of memlers of the Nomencl ature Cominitee

There were threc proposals for anendment of Rule 24 . The first had been made ef the $\mathrm{Co}$ penhagen Congress and its object vias to make illegilimate any generic name of more than six syllables This proposal was by leave, withdrarn lite second proposal was one to meke illegilimele liaks of gonera and species that are not ascquetely characteriaco After discussion it was deeided that il would be very difficult io draw up sum a rule and ther the propeser shuilu be irviced to frams a definite aneninent

The third amendmont was intented to correck an eiror that had been overlogked when the Codo was approved et $\mathrm{Co}$ penhagen In the fourto para Eraph of Rule 24 the word genus was incorrectly used for "laxonomic group", anc it was agred that an appropriate correction shouid be mase.

The cesiralifity of chanen. Fule $2 \%$ Reconmenation zh

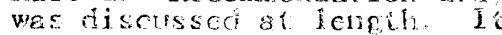
vas serece fret classicel gentive entinks should be used in specific epithets formed from Latin and Greek 


\section{INTERNATIONAL BULLETIN}

patronymics, The use of the terminal. $i i$ for other patro nymics was the subject of criticism and, by a small majority, the Commission re commended the use of a single However, the Committee referred the matter to the Editorial Board for further consideration, and a final ballot of all members of the Committee will be held

$$
\begin{aligned}
& \text { Nomina ronservanáa and } \\
& \text { numina tejtienáa }
\end{aligned}
$$

Two diametrically opposed proposals concerning the gener ic name Barte: ivm and the family name $B$ a betace were before the Commission: one re quested that these names be made riomina rejo ienda: and the other that they be made nomina consevanda. It was decided to take a ballot of members present and to ask absent commissioners to vote by post

$$
\begin{aligned}
& \text { Opinions isswea by } \\
& \text { the Commisson }
\end{aligned}
$$

An Opinion was prepared as a model for discussion and the Chairman asked commissioners to comment on its form Two opinions were issued and are reproduced in this issue of the BULLETIN

Swowhthe A the work oj

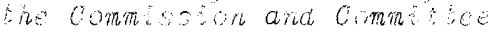

It was decided to ask per mission of the Plenary Session to forward to UNESCO an appli cation for a subvention for the work of the Commission and Committee Secretarial ex penses and postage costs were considerable and were steadily increasing as the work of the Commission and Committee in creased; until now these ex penses had been borne entirely by members and by the inst $i$ tutes to which the members were attached

$$
\text { Repori: of Subcommitrees }
$$

The Subcommittees on Tax onomy as organized since the
Copenthagen Congress, $i$. the Subcommittee on Neisseria, Sub committee on Medical and Vet erinary Mycology. Subcommit tee on Viruses Subcomittee on Pneumococcus and the Subcom. mittee on $L e p t 0 s p r a$, were all accepted as functioning Sub. committees of the parent Nomen clature Committee The recom mendation of the Pneumococcus Subcommit tee that it be merged with the Stretrocoutis Subcom. mittee was accepted. Likewise the recommendation of the Phytopathological Section of the Congress that the Virus Subcommittee be subdivided into Animal and Plant Sections was not only accepted but it was also decided to add a third section to the Subcomittee to consider the classification of Bacterial Viruses

Several new subcommittees had been proposed during the Congress and it was agreed that their formation should be dealt with under the amended Provision 4 of the Bacteriological Code

It was agreed to authorize the publication of eports that had been read before Section 11 of the Congress but it was essential to point out that these reports did not necessar ily represent the views of the Nomenclature Committee which reserved to the Commission the right to consider ail problems of nomenclature

The Erterobacteraceac Sub committee recommended that the Wox Id Heal th Organization should be asked to extend the International Salmone 11 a Centre at Copenhagen into a Salmonella and Escine ichia centre and that two sinigel? a Centres should be established, an International Centre at Chamblee, Georgia U S A and a British Commonwea1 th and European Centre at Oxfo:d These recommendations were approved and were forwarded to W. H.O 


\section{BACTERTOLOGICAL NOMENCLATURE AND TAXONOMY}

The Virus Subcommittee made two recomendations on the no menciature of viruses and both were approved They were firstly that the starting date of virus nomenclature should not be considered until the next international nicrobiological congress and secondly that the use of a comprehcinsive system of nomenclature for virus is at present unwise
The provisional subcommittee on ic piepira was authorized. and the provisional subcomittee on pneumoccoccus was combined with the subcommittee on strep tococcus Several new subcom Tit tees had been proposed during the Congress and it was agreed that their formation should be dealt with under the new Pro vision 4 of the Eacteriological Conde 